\title{
GOSPODARKA
}

\section{Bartosz Woliński}

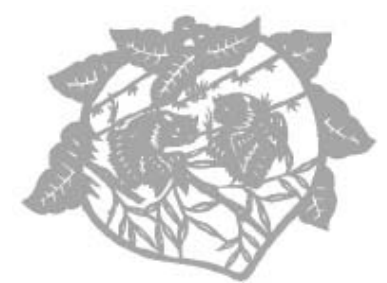

\section{RESTRUKTURYZACJA I PRYWATYZACJA CHIŃSKICH PRZEDSIĘBIORSTW}

Pod koniec lat 70. sektor przedsiębiorstw państwowych (State Owned Enterprises $S O E$, reprezentowany przez ponad 100 tysięcy podmiotów gospodarczych, zatrudniał ponad 70 proc. chińskich pracowników i był odpowiedzialny za prawie 40 proc. PKB. Znaczenie tego sektora sukcesywnie jednak malało od chwili rozpoczęcia reform: w 1980 r. przedsiębiorstwa państwowe wytwarzały 76 mld RMB produkcji przemysłowej brutto, w $1995 \mathrm{r}$. - 28,5 mld RMB., a w 2003 r. już tylko 18,5 mld RMB. Głównymi gałęziami były i nadal są - przemysł elektromaszynowy, wydobywczy, chemiczny, przetwórczy i tekstylny. Nie bez znaczenia pozostawał również przemysł zarządzany przez wojsko, będący niezwykle trudnym elementem reform.

Po prawie 30 latach reform kłopoty finansowe, przerost zatrudnienia, nieefektywna i kosztowna produkcja należą do najważniejszych bolączek trapiących sektor przedsiębiorstw państwowych w Chinach. Według raportów Banku Światowego i chińskiego Narodowego Biura Statystycznego (National Bureau of Statistics, dawniej: State Statistical Bureau) od początku lat 90. ponad połowa przedsiębiorstw przynosi straty, a wskaźnik zadłużenia w całym sektorze do aktywów wynosi 75-80 proc., z czego 30 proc. przedsiębiorstw notuje zadłużenie przewyższające aktywa ${ }^{1}$, dochodzące nawet do 500 proc. Jednocześnie wiele przedsiębiorstw państwowych utrzymuje produkcję poniżej swoich możliwości produkcyjnych, osiagając poziom nawet 10 proc. możliwości.

Przedsiębiorstwa państwowe pełniły także funkcje społeczne. Stanowiły one tzw. jednostkę pracy - danwei, która była niezwykle ważna w Chinach i w praktyce oznaczała znacznie więcej niż po prostu miejsce pracy. Stanowiła podstawę, w jaki sposób dana osoba była identyfikowana i kontrolowana. Udzielała zezwoleń na zamążpójscie, zmianę miejsca pracy, posiadanie dzieci itd., gwarantowała dożywotnią pracę i skromną eme-

1 Communique of the Third National Industrial Census 1997, State Statistical Bureau, Beijing 1998, China Statistial Yearbook, różne lata. 
ryturę. Upadek wielu przedsiębiorstw państwowych oznaczał likwidację danwei, a tym samym bezrobocie i brak jakiegokolwiek zabezpieczenia i opieki socjalnej dla milionów Chińczyków.

Z uwagi na równoczesny brak umiejętności, rozmytą odpowiedzialność i brak mechanizmów motywacyjnych dla urzędników państwowych, będących przedstawicielami właściciela z politycznego nadania, przedsiębiorstwa państwowe nie są efektywnie monitorowane i zarządzane (choć należy zwrócić uwagę, że ekonomiczna efektywność nie była wcale priorytetem w gospodarce socjalistycznej). Brak właściwego, z finansowego punktu widzenia, nadzoru jest efektem, pokutującego również w Polsce, stwierdzenia: „państwowa, obywatelska własność jest niczyją własnością”2. Brak poczucia odpowiedzialności wynika również z faktu, że scentralizowaną, dyrektywną formę zarządzania przemysłem utrzymano w Chinach aż do października 1984 r., kiedy to III Plenum KC KPCh XII kadencji ${ }^{3}$ uchwaliło odejście od tej praktyki ${ }^{4}$.

Restrukturyzacja przedsiębiorstw państwowych tym samym stała się najtrudniejszym problemem, przed jakim stoją władze ChRL, a jednocześnie zadaniem pierwszoplanowym, gdyż są one poważną barierą rozwoju gospodarki ChRL ${ }^{5}$. Co prawda pewne próby reformowania przedsiębiorstw państwowych były podejmowane od samego początku procesu transformacji, zasadnicze jednak podejście do tego problemu nastapiło dopiero w 1997 r., kiedy to podjęto decyzję o restrukturyzacji tysiąca dużych przedsiębiorstw państwowych oraz tych małych i średnich przedsiębiorstw państwowych, które przynosiły straty ${ }^{6}$.

Równolegle nie można mówić o „powszechnej” zmianie struktury własnościowej przedsiębiorstw państwowych. Mimo prywatyzacji, komunalizacji czy uspołecznieniu olbrzymiej większości drobnych i średnich przedsiębiorstw państwowych (sklepów, restau-

2 R. H. Coase, The Problem of Social Cost, ,Journal of Law and Economics”, 3 (1), Chicago 1960, s. 1-44.

3 B. Kikolski, Plany rozwoju gospodarczego Chin, „Azja-Pacyfik” Tom I (1998), Wydawnictwo Adam Marszałek, Toruń 1998, s. 135.

4 Zniesiony został jednocześnie dogmat o monopolu własności uspołecznionej w przemyśle. Zaczęto powiększać zakres autonomii przedsiębiorstw państwowych, a w przedsiębiorstwach uspołecznionych wprowadzono możliwość zawierania kontraktów menedżerskich. Zezwolono także na modyfikację państwowego monopolu własnościowego i tworzenie spółek podmiotów publicznych.

5 P. Mar, M. N. Young, Corporate Governance in Transition Economies: A Case Study of Two Chinese Airlines, „Journal of World Business” nr 36 (3), Columbia University, New York 2001, s. 282

6 Pozostawienie przemysłu państwowego na wiele lat, niemal bez zmian, obok sektorów reformowanych i nowotworzonych, było świadomą decyzją. Wszędzie SOE były wielkim problemem, także w Polsce, ale w Chinach można było zaawansować reformy niemal nie ruszając sektora przedsiębiorstw państwowych. Zreformowano zatem np. rolnictwo i stworzono nowe sektory prywatne, czy też utworzono wiele joint-ventures. A do reform SOE przystąpiono, gdy cała gospodarka już się zdynamizowała i rozwinęła. 
racji, zakładów usługowych, zwłaszcza przynoszących straty) ${ }^{7}$, rząd ChRL nie zamierza rezygnować z państwowego sektora w przemyśle. Wskazuje wręcz na jego dominującą rolę . Dopuszcza się natomiast możliwość przejmowania częściowego lub pełnego przedsiębiorstw państwowych (szczególnie małych i średnich) przez kapitał prywatny lub zagraniczny, ale to dotyczy z reguły przedsiębiorstw zadłużonych i przynoszacych straty oraz mało istotnych z punktu widzenia interesów bezpieczeństwa gospodarczego. I ta koncepcja prywatyzacji cieszy się sporym zainteresowaniem, a tym samym dużą dynamiką. Przemysł obronny i gałęzie strategiczne ${ }^{9} \mathrm{z}$ punku widzenia niezależności gospodarczej pozostają $w$ rękach państwa ${ }^{10}$. Zakres tego pojęcia jednak stopniowo zmniejszano i przykładowo regulacje prawne z 2005 r. przewidują ograniczenia głównie w działalności związanej z telekomunikacją i specjalistycznymi środkami łączności oraz środkami masowego przekazu. Dodatkowo w ChRL zabronione jest tworzenie przedsiębiorstw, które naruszają suwerenność i prawo Chin, kolidują z wymogami rozwoju gospodarczego, zanieczyszczają środowisko naturalne, a także tych, w umowach założycielskich których znajdują się zapisy świadczące o braku równości między stronami ${ }^{11}$.

7 Po zjeździe partii w 1997 r., kiedy to Jiang Zemin zapowiedział zmiany w statusie dużych zakładów państwowych, niektórzy działacze lokalni wzięli się do prywatyzacji z taką energią, że Pekin musiał studzić ich entuzjazm i ostro przyhamować (choćby ze względu na przyrastające ilości kredytów udzielanych władzom lokalnym na przedsprzedażowe polepszenie jakości przedsiębiorstw). Wciąż jednak prywatyzacja postępuje - choć z przyczyn ideologicznych unika się tego słowa. Istnieje nawet opinia wśród działaczy komunistycznych, że transfer firm w prywatne ręce nie jest prywatyzacją wtedy, gdy sprzedaje się je korporacjom, a nie osobom prywatnym.

${ }^{8}$ Stanowisko w tej sprawie zmieniało się, a jeszcze bardziej interpretacje „własności społecznej”, bo to o nią chodzi, a nie o „państwową".

9 China Report, ILT February 2000, The Economist Intelligence Unit Ltd, Londyn 2000.

${ }_{10}$ Co do zasady jednak zmiana roli państwa w gospodarce ChRL postępuje. Polega ona z jednej strony na wspomnianym ograniczeniu jego roli jako podmiotu działalności gospodarczej, z drugiej zaś - na odchodzeniu od bezpośredniego sterowania procesami gospodarczymi w formie nakazów na rzecz pośredniego oddziaływania m.in. poprzez politykę monetarną, fiskalną czy budżetową. Tej doktrynalnej wręcz zmianie roli państwa $\mathrm{w}$ gospodarce służy reforma administracji państwowej. I tak - Ogólnochińskie Zgromadzenie Przedstawicieli Ludowych uchwaliło w marcu 1999 r. przeprowadzenie reformy administracji państwowej w ciagu 3 lat. Podstawowe jej elementy są następujące: zdjęcie odpowiedzialności z rządu za przedsiębiorstwa państwowe, zmniejszenie wydatków rządowych, usprawnienie struktury i działalności rządu. W tej ostatniej kwestii dokonano już w 2000 r. pewnych zmian zmniejszając ilość ministerstw i komisji z 41 do 29, określając od nowa zakres ich kompetencji. $\mathrm{O}$ połowę zmniejszono również zatrudnienie $\mathrm{w}$ instytucjach centralnych. W ramach reformy administracji wprowadzono zakaz prowadzenia działalności gospodarczej przez chińską armię i policję oraz organizacje rządowe i partyjne (w ramach walki z korupcja).

11 Por.: Compilation of Laws and Regulations concerning Foreign Investment in China, compiled by Information Office of the State Council of the People's Republic of China, China Intercontinental Press, Pekin 2001. 


\section{Program reform przedsiębiorstw państwowych}

W celu uzdrowienia sytuacji dużych przedsiębiorstw państwowych ${ }^{12}$, zatrudniających czasami kilkunastotysięczne załogi, wprowadzono czterostopniowy program reform, dzięki któremu uniknięto porównań procesu przekształceń do ideologicznie niewłaściwej bezpośredniej prywatyzacji. Chodziło nie tylko o „prywatyzację” jako mechanizm kapitalistyczny, ale o „wyprzedaż obcemu kapitałowi” ${ }^{13}$. A prywatnego kapitału rodzimego przecież jeszcze nie było.

Wstępny etap, rozpoczęty w 1979 r. ${ }^{14}$, ukierunkowany był na zatrzymanie i zwiększenie zysków w przedsiębiorstwach. Drugi etap dotyczył wprowadzenia systemu podatków od zysków, uruchamianego dwustopniowo (w 1983 r. i 1984 r.). Trzeci - pomiędzy 1987 r. a 1992 r. - skupił się na wprowadzaniu zasad zarządzania rynkowego oraz podstaw pod ład korporacyjny w przypadku potencjalnych spółek giełdowych. Czwarty etap, od 1993 r., skierowany do dużych przedsiębiorstw, obejmował korporacyjną reorganizację (korporatyzację) przedsiębiorstw na bazie tzw. modern enterprise system (MES) i w oparciu o wydane w grudniu 1993 r. Prawo korporacyjne (Chinese Corporate Law).

W ramach pierwszego etapu umożliwiono rentownym przedsiębiorstwom zatrzymanie części zysków przeznaczonych na stworzenie trzech niezależnych funduszy: na rozwój produkcji, zabezpieczenia majątkowego pracowników oraz na premie. Działania te miały motywować kierownictwo przedsiębiorstwa do zwiększania rentowności zakładu.

Kolejny etap był kontynuacją działań zmierzających do lepszego gospodarowania zyskiem w przedsiębiorstwach państwowych. Zamiast oddawać wypracowany zysk przedsiębiorstwo mogło oddać określoną jego część, zatrzymując resztę zysku na własne potrzeby. W praktyce zdarza się jednak, że od tej zachowanej części przedsiębiorstwo płaci jeszcze podatek.

Przedostatni etap zmierzał do stworzenia ram dla ładu korporacyjnego zgodnego ze światowymi standardami (corporate governance), odnoszącego się do strategicznych,

12 Według wytycznych State Economic and Trade Commission - SETC, za duże przedsiębiorstwo uznaje się zakład, który wykazuje łączną sprzedaż i środki własne na poziomie przewyższającym 500 mld RMB.

13 Prywatyzację przeprowadzano starając się, by zakłady pozostały „w rękach chińskich”, z kraju i z zagranicy (w rękach huaqiao - „zagranicznych Chińczyków” z Hongkongu, Tajwanu, Singapuru itd.). Kapitał obcy dopuszczano, ale ostrożnie. Stąd polityka była skomplikowana, ale skuteczna i zapewniająca dużo większe bezpieczeństwo inwestycji zagranicznych.

14 Jednak już od 1972 r. dokonywano rozmaitych zmian w gospodarce z inicjatywy kadr lokalnych, zwiększano rolę mechanizmów rynkowych pod „,parasolem politycznym” Zhou Enlaia i wykorzystując zainteresowanie „,bandy czworga” głównie sprawami ideologii. Podejmowano różne eksperymenty, jedne Pekin zwalczał, inne się przebijały. Nawet przed rewolucją kulturalną $S O E$ były bardziej dynamiczne i samodzielne niż ówczesne polskie. 
długofalowych procesów zarządzania, kreujących wartość dodaną dla firmy i jej otoczenia, zmierzających jednocześnie do zapewnienia przejrzystości działania ${ }^{15}$.

W ostatnim etapie, zgodnie z wytycznymi XV Zjazdu KPCh (wrzesień 1997 r.), Komitet Centralny zaakceptował próbny plan przekształcenia dużych i średnich przedsiębiorstw państwowych w spółki akcyjne (gufen youxian gongsi) lub spółki z ograniczoną odpowiedzialnością (youxian zeren gongsi) ${ }^{16}$. W 1994 r. rząd rozpoczął również eksperyment reformowania małych i średnich przedsiębiorstw w 18 pilotażowych miastach, a od końca lat 90. eksperyment polegający na oddłużaniu firm i przekwalifikowaniu zwalnianych pracowników prowadzony jest w 111 miastach $^{17}$. Oficjalne dane stanowią, że w latach 1998-2000 ponad 13 mln bezrobotnych zostało przekwalifikowanych, z czego 60 proc. zostało ponownie zatrudnionych ${ }^{18}$.

V Plenum KPCh XV Zjazdu KPCh, zatwierdziło po analizie wyników programu reform $^{19}$-zarówno korporatyzację dużych $S O E$, jak i przyspieszenie reform. Najistotniejszym

15 Ład korporacyjny obejmuje ogólnie kwestie związane ze składem zarządu i rady nadzorczej, możliwością kontroli ze strony dużych i instytucjonalnych udziałowców, instytucji finansowych i graczy rynkowych. Reguluje też kwestie uczciwego ustalania cen akcji. Należy w tym kontekście uwypuklić specyfikę chińskiego otoczenia rynkowego, w którym kontrola ze strony banków praktycznie nie istnieje. Banki państwowe pełnią rolę „kasjerów” dla przekształcanych przedsiębiorstw państwowych, co jest jedną z przyczyn tzw. „złych długów”, omówionych szerzej w części dotyczącej sektora finansowego w ChRL.

16 Duża część reform $S O E$ jest w istocie bliska znanej z polskich doświadczeń komercjalizacji - i w tej formie wprowadzała $S O E$ na rynek.

17 R. Smyth, Toward „the Modern Corporation” : Recent Developments in the Institutional Reform of State - Owned Enterprises in Mainland China, „Issues \& Studies” 1998 nr 8, s. 104.

18 Władze chińskie dość dużo uwagi przykładają do aktywizowania bezrobotnych z SOE poprzez zwiększenie powszechności edukacji, szkolenia dla bezrobotnych. Jednak rzeczywistość odbiega od założeń planistów, a oficjalne dane charakteryzuje duża dysproporcja w stosunku do codziennych obserwacji. Por.: Labor and Social Security in China, Information Office of the State Council of the People"s Republic of China, Beijing 2001, s. 9.

19 Strategia przedstawiona przez Deng Xiaoping'a była rozbudowaną wersją koncepcji zaproponowanej uprzednio w 1975 r. przez premiera Zhou Enlaia. Kierowano się w niej zasadą pragmatyzmu, tj. wprowadzania takich rozwiązań, które będą skuteczne niezależnie od tego, czy są one zgodne z obowiązującą w Chinach ideologią. Należy jednak mocno podkreślić, że chińskie reformy nie były i nie są realizacją programu w pełni teoretycznie i operacyjnie zdefiniowanego. Szereg środków polityki gospodarczej zastosowano intuicyjnie, często opierając się na posunięciach eksperymentalnych. Chińskie kierownictwo zrozumiało współzależność między rozwojem gospodarczym oraz utrzymaniem władzy i w swojej polityce reform w wielu aspektach podążało za spontanicznymi tendencjami gospodarowania panującymi wśród ludności wiejskiej oraz miejskiej. W ten sposób właściwe treści reformy rolnej (rozdawnictwo ziemi dla gospodarstw domowych) oraz prywatna działalność gospodarcza w drobnym handlu i rzemiośle w rejonach nędzy rozpowszechniły się samoistnie i dopiero kiedy okazały się wysoce produktywne i skuteczne, były eksploatowane w skali całego kraju jako ,program reform”. Spontaniczny proces przemian wciąż na nowo rozsadzał przyjęte przez partię założenia i inicjował w ten sposób zmiany, początkowo nawet nie zamierzone przez kierownictwo partii w tej formie, i jeszcze pod koniec lat 80. traktowane jako „heretyckie”. Jest zresztą rzeczą powszechnie uznawaną, że brak jednolitej 
elementem programu reform stało się hasło: „opanowanie dużych, ożywienie małych” (polityka określana mianem zhuada, fangxiao od nazw dużych przedsiębiorstw, które kontrolowane i restrukturyzowane są przez państwo i relatywnie małych, których państwo pozbywa $\left.\operatorname{sie}^{20}\right)$. „Opanowanie dużych” obejmuje tworzenie przez władze centralne holdingów przedsiębiorstw państwowych z szeroką grupą właścicielską (przede wszytkim w kluczowych sektorach - pillar industries) oraz zmianę struktury właścicielskiej. Zmiana struktury nastepuje poprzez zachęcanie zarządów do wchodzenia na giełdę (listed companies) w celu zdywersyfikowania struktury własności i zebrania kapitału potrzebnego na restrukturyzacje $e^{21}$. „Ożywianie małych” umożliwia eksperymentowanie z różnymi formami własności i zarządzania w małych i średnich $S O E$, m.in. przeprowadzaniem upadłości, fuzjami i reformami struktur udziałowych.

Chęć pozbycia się małych i średnich $S O E$ wynika przede wszystkim z tego, że ten segment rynku przedsiębiorstw państwowych przynosi większą część strat. Duże przedsiębiorstwa zajmują w dużej mierze monopolistyczną lub oligopolistyczną pozycję, co przekłada się na lepsze (co nie oznacza dobre) wyniki finansowe.

\section{Sytuacja finansowa przedsiębiorstw państwowych}

Sytuacja finansowa przedsiębiorstw państwowych znacznie pogorszyła się w okresie reform: liczba przedsiębiorstw przynoszących straty wzrosła z 19,2 proc. w $1980 \mathrm{r}$. do 37,7 proc. w 1996 r., a całkowity deficyt wzrósł z 3,4 mld RMB do 79,1 mld RMB i trend ten utrzymywał się przez następną dekadę. Jednocześnie drastycznie spadła wielkość produkcji przemysłowej przedsiębiorstw państwowych, co prezentuje tabela 1.

linii prowadzonych reform jest zaliczany do jednych z najważniejszych przyczyn rewolty na Placu Tiananmen. Twierdzenie, że przekształcenia gospodarki chińskiej były stopniowe i rozłożone w czasie wynikają także z obserwacji przebiegu transformacji. Praktycznie żadne zmiany nie były gwałtowne, często były wprowadzane połowicznie, aby sprawdzić efekt (również polityczny) i w razie potrzeby wycofać się z zaproponowanego planu. Wiele rozwiązań wstępnie było wprowadzanych jedynie lokalnie - w jednej prowincji, mieście, w myśl zasady „uczenia się na błędach”. Jest to także w pewnym stopniu negacja stylu rządzenia Mao, który przeprowadzał eksperymenty gospodarcze na skalę kraju, niejednokrotnie bez refleksji na temat ewentualnych konsekwencji.

20 C. A. McNally, P. Nan-Shong Lee, Is Big Beautiful? Restructuring China's State Sector under the Zhuada Policy, „Issuses \& Studies” 1998, nr. 9, s. 22-48.

21 Por. Z. Wenkui, Restructuring of China's Listed Companies: Achievements and Problems, „China Development Review”, Vol. 3. No. 1., Pekin 2001, s. 37-49. 
Tabela I. Wielkość produkcji przemysłowej według wybranej struktury własności w mld RMB

\begin{tabular}{|l|c|c|c|c|c|c|}
\hline & $\mathbf{1 9 8 0}$ & $\mathbf{1 9 8 5}$ & $\mathbf{1 9 9 0}$ & $\mathbf{1 9 9 5}$ & $\mathbf{2 0 0 0}$ & $\mathbf{2 0 0 3}$ \\
\hline Przedsiębiorstwa państwowe & 76 & 64,9 & 54,6 & 28,5 & 23,5 & 18,5 \\
$\begin{array}{l}\text { Inne przedsiębiorstwa (joint ventu- } \\
\text { re, zagraniczne przedsiębiorstwa, } \\
\text { spółki akcyjne, przedsiębiorstwa } \\
\text { prywatne) }\end{array}$ & 0,5 & 3,1 & 9,8 & 32,1 & 45,2 & 48,9 \\
\hline
\end{tabular}

Źródło: China Statistical Yearbook, różne lata.

Jedną z ważniejszych przyczyn złych wyników finansowych jest wspomniane we wstępie obciążenie bagażem socjalnym, spuścizną wielu lat komunizmu, kiedy każdy Chińczyk miał zagwarantowane ubezpieczenie zdrowotne, emeryturę, czy też powszechnie znaną ,żelazną miskę ryżu”. Władze chińskie starają się tę sytuację podtrzymywać, przede wszystkim w obliczu braku powszechnego systemu opieki społecznej i starzejącego się społeczeństwa. Według Banku Światowego liczba osób, którym przysługuje świadczenie emerytalne wzrośnie z $76 \mathrm{mln}$ w 1995 r. do $300 \mathrm{mln}$ w 2050 r., a jednocześnie stosunek pracowników do emerytów zmniejszy się odpowiednio z 10:1 do 3:122. Wydatki na opiekę socjalną wzrosły z 11,6 mld RMB w 1980 r. do 196,1 mld RMB w 1995 r. (badania przeprowadzone w 28 przedsiębiorstwach państwowych wykazały, że każdy robotnik w 1995 r. otrzymał przeciętnie 844 RMB na opiekę zdrowotną, 582 RMB na utrzymanie domu i 324 RMB na bezpłatną edukację) ${ }^{23}$. W 1995 r. udział wydatków na opiekę medyczną i emerytury w ogólnej kwocie wydatków na opiekę socjalną wynosił 82,1 proc., (wzrósł on z 66 proc. w 1980 r.). Rosnące koszty opieki nad osobami starszymi i niepełnosprawnymi, byłymi pracownikami, które przedsiębiorstwa państwowe zmuszone są pokrywać z bieżących przychodów, utrudniają im wypełnianie restrukturyzacyjnych zobowiązań związanych z redukcją zadłużenia ${ }^{24}$. Brak spójnej polityki zabez-

222020 Pension Reform in China: Old Age Security, The World Bank, Waszyngton 1997.

23 R. Smyth, Toward, cyt. wyd., s. 106.

${ }^{24} \mathrm{~W}$ tym miejscu konieczne wydaje się wspomnienie w kontekście sytuacji robotników o sprzedaży $S O E$ inwestorom prywatnym - najczęściej są to zagraniczne organizacje. Z jednej strony państwo gwarantuje dożywotnią pracę i jednocześnie dzięki temu oczekuje spokoju społecznego, a z drugiej wymogi prywatnego inwestora i rynkowych mechanizmów nie pozwalają utrzymać dotychczasowego poziomu zatrudnienia. Ciekawą propozycję (jak na warunki ChRL) w tej kwestii przedstawiły władze Szanghaju. Pracownicy wraz ze zmianą typu przedsiębiorstwa stają się pracownikami firmy komercyjnej bez gwarancji dożywotniej pracy, ale kupiec $S O E$ jest zobowiązany zapłacić wszystkim pracownikom (bez znaczenia, czy przedłuża z nimi umowę o pracę, czy też nie) za utratę pewności zatrudnienia - „opłaty za wykup dożywotniej gwarancji pracy” (fees to buyout the service year). Opłata taka jest skalkulowana następująco: roczne zarobki (przeciętnie w Szanghaju wynoszą one 6420 RMB, co stanowi równowartość 773,52 USD) pomnożone przez liczbę lat pracy. Równolegle nowy pracodawca przejmuje obowiązek dopłaty do czynszów 
pieczeń socjalnych (zaczątki jednolitej polityki, gwarantującej minimum zabezpieczenia, funkcjonują jedynie w regionach miejskich - $\mathrm{i}$ to od niedawna, gdyż dopiero w $2001 \mathrm{r}$. wdrożono program pilotażowy w prowincji Liaoning ${ }^{25}$ i powszechnej opieki medycznej jest tym samym jedną z najważniejszych przeszkód blokujących zdecydowane reformy przedsiębiorstw państwowych. Likwidacja tychże (co w przypadku SOE jest często jedynym wyjściem) skazuje byłych pracowników na nędzę. Stworzenie w 2001 r. centralnej administracji (National Social Security Fund Executive Council) zarządzającej funduszami socjalnymi oraz przyjęcie w 1998 r. polityki „dwóch gwarancji” - gwarancji minimum socjalnego dla zwalnianych pracowników $S O E$ oraz emerytów - jest raczej fasadą, za którą kryje się ogrom problemów społecznych nękających Chiny ${ }^{26}$.

Innym czynnikiem odpowiedzialnym za złe wyniki finansowe przedsiębiorstw państwowych jest system cen dualnych (dual-track pricing). Przedsiębiorstwa państwowe notujące straty z tego tytułu reprezentuja przede wszystkim przemysł wydobywczy ropy, gazu i węgla, gdzie ceny sprzedaży zostały ustalone poniżej kosztów, co wpłynęło zdecydowanie negatywnie na stosunek zysku do kapitału.

Pierwszą kategorię stanowią ceny będące pochodną w miarę swobodnej relacji kupujący-sprzedający, która występują w rozwiniętych gospodarkach rynkowych. Na drugą kategorię składają się ceny ustalane w różny sposób przez organy państwowe: poprzez zarządzenia, wytyczne lub na drodze ustaleń. Wydzielenie dwóch kategorii cenowych miało na celu uniknięcie szokowej terapii, która mogła spowodować niepokoje społeczne. W zamierzeniu władz różnica pomiędzy kategoriami cenowymi miała być stopniowo redukowana tak, aby minimalizować ekonomiczne i społeczne zakłócenia. Ceny rządowe (ustalane przez rząd) miały być zbliżane do cen quasi wolnorynkowych, co miało spowodować stopniową likwidację cen kontrolowanych przez państwo. Mimo wielu przeszkód, cele, jakimi są ujednolicanie cen i rezygnacja z ich kontroli, są konsekwentnie utrzymywane - osobną kwestią jest tempo ich realizacji ${ }^{27}$. Zgodnie ze źródłami chińskimi, udział cen produktów rynkowych determinowanych przez siły rynkowe wzrósł z 52 proc. w 1990 r. do 79 proc. w 1994 r. (zmiana w odniesieniu do cen produktów przemysłowych była jednak głębsza - z 53 proc. w 1990 r. do 90 proc. w 1994 r.) i utrzymuje się na po-

mieszkaniowych. Dodatkowo zwolnionym pracownikom opłacone zostają trzy składki ubezpieczenia, obejmującego ubezpieczenie zdrowotne, emerytalne i na wypadek bezrobocia. Wszelkie wymienione wyżej opłaty wpływają oczywiście na ostateczną cenę zakupu przedsiębiorstwa. C. Devonshire-Ellis, Purchasing State - Owned Enterprises, „Beijing Review”, 9 października 2003, s. 36.

${ }_{25}$ Labor and Social Security in China, cyt. wyd., s. 20.

26 B. Woliński, Procesy transformacji ustrojowej gospodarki Chińskiej Republiki Ludowej $i$ ocena jej efektów, praca doktorska, Uniwersytet Gdański, Wydział Ekonomiczny, Sopot 2005, s. 209.

27 Proces zbliżania cen nie jest procesem dynamicznym. Nadal wiele kategorii cen (szczególnie o dużym znaczeniu dla gospodarki ChRL) jest kontrolowanych przez państwo. Wynika to z dwóch czynników: poziomu materialnego większości społeczeństwa oraz obaw władz dotyczących protestów wynikających z podwyżek (w okresie transformacji urynkowienie cen najczęściej oznacza sporą ich podwyżkę). 
ziomie około 85 proc. na początku XXI w. Są to jednak tylko uśredniane dane, które nie uwzględniają wielu aspektów chińskiej gospodarki okresu przejściowego. Nadzór państwowy może przyjmować wiele subtelnych form, które niezwykle trudno zakwalifikować jako bezpośredni wpływ na wysokość cen; umykają one prawnym i statystycznym definicjom.

W odniesieniu do przemysłu maszynowego i tekstylnego, który pod koniec lat 80 . podlegał już w pewnym stopniu regulacjom rynkowym (poza przemysłem produkującym maszyny rolnicze i ciężki sprzęt, gdzie ceny nadal ustalało państwo), przyczyny strat należy upatrywać w spadku wolumenu sprzedaży. Przedsiębiorstwa zanotowały nadprodukcję, a jednocześnie nie były w stanie elastycznie kierować rozmiarami produkcji, tak by dostosować go do nadpodaży.

Do kłopotów finansowych przyczyniają się także różnorodne opłaty, podatki, które niejednokrotnie, $\mathrm{z}$ racji tego, że częstokroć ustalane są lokalnie, przewyższają poziomy opłat np. przedsiębiorstw prywatnych, a także postawa zarządców przedsiębiorstw - biurokratów. Korzystają oni ze swojej pozycji, braku kontroli właścicielskiej i zamieszania związanego z transformacja, aby wyprowadzać niejednokrotnie ogromne majątki przedsiębiorstw na swoje prywatne konta ${ }^{28}$.

\section{Restrukturyzacja dużych i średnich przedsiębiorstw państwowych}

W sytuacji rozkładu chińskich finansów publicznych bardzo istotną decyzją było rozpoczęcie procesu restrukturyzacji dużych i średnich przedsiębiorstw państwowych (Large and Medium-Sized SOE - LME). 1000 największych przedsiębiorstw państwowych, spośród których 878 reprezentuje przemysł, stanowi jedynie około 3 proc. wszystkich przedsiębiorstw państwowych, ale równolegle reprezentuje ponad 60 proc. wszystkich zasobów, produkcji, sprzedaży i przychodu.

Transformacja LME (zhuada) zgodnie z wytycznymi KC KPCh, uzgodnionymi na XIV Zjeździe Partii, skupiła się na wybraniu kluczowych przedsiębiorstw w celu uzyskania ekonomii skali i optymalnej alokacji zasobów ${ }^{29}$. Obejmuje ona trzy etapy:

1. przekształcenie w spółkę z ograniczoną odpowiedzialnością lub akcyjną;

2. wprowadzenie przekształconych, rentownych przedsiębiorstw na giełdy w Szanghaju, Shenzhen, Hongkongu lub Nowym Jorku;

3. konsolidacja w grupach przemysłowych.

${ }_{28}$ K. Lee, Property Rights and the Agency Problem in China's Enterprise Reform, „Cambridge Journal of Economics" nr 17, Cambridge 1993, s. 179-194.

29 P. Nan-shong Lee, Industrial Management and Economic Reform in China, 1949-1984, Oxford University Press, Hongkong, Nowy Jork i Londyn, 1987, s. 75-78, 149-69. 
Założenia, na podstawie których przeprowadzona zostać miała skuteczna trójstopniowa transformacja, opierały się na dwóch elementach. Pierwszym z nich było przekazanie zarządom przedsiębiorstw daleko idącej autonomii i zlikwidowanie politycznego obciążenia $^{30}$. Punktem zwrotnym w realizacji tego założenia było wejście w życie Ustawy o przedsiębiorstwach (Enterprise Law) w 1988 r. i wprowadzenie 25.07.1992 r. tzw. „nowego mechanizmu działalności" (New Operating Mechanism - NOM ${ }^{31}$ ), pozwalającego władzom firm m.in. na niezależne inwestycje i dysponowanie środkami własnymi.

Drugim elementem było stworzenie struktury zarządzania środkami państwowymi przeprowadzonej do 1996 r. głównie w Szanghaju, Shenzhen, Tianjinie, Deyangu, Quanzhou. Od tego momentu obserwuje się jednak działania pozostałych władz lokalnych zmierzających do stworzenia podobnej struktury. Polega ona pierwsze na rozdziale obowiązków i praw pomiędzy zarządem a właścicielem poprzez powołanie Komitetów Administracji Środkami Publicznymi (State-Owned Asset Administration Committees; guoyou zichan guanli weiyuanhui) wraz biurami lokalnymi (guoyou zichan guanli bangongshi), będącymi jedynym reprezentantem praw właścicielskich państwa. Następnym krokiem było utworzenie państwowych korporacji holdingowych (State Holding Corporations - guoyou konggu gongsi), które kształtują przed wszystkim układ personalnej odpowiedzialności (rengehua) za decyzje podejmowane przez zarządy (ich koncepcja przypomina polskie Narodowe Fundusze Inwestycyjne).

Celem przekształcenia $S O E$ w spółkę z ograniczoną odpowiedzialnością jest oddzielenie roli państwa, jako zarządcy, od zarządzania przedsiębiorstwem oraz zarządzania przedsiębiorstwem od praw własności - początkowo proces ten był niezwykle powolny: przykładowo w 1994 r. we wschodniej prowincji Zhejiang tylko 67 spółek z ograniczona odpowiedzialnością na 1067 zarejestrowanych, było uprzednio przedsiębiorstwami państwowymi ${ }^{32}$. Z czasem nabierał on tempa - pod koniec $1997 \mathrm{r}$. spółki z o.o. stanowiły 25 proc. wszystkich $L M E ; 107$ z nich znajdowało się pośród 500 największych chińskich przedsiębiorstw przemysłowych, a 62 pośród 500 największych chińskich przedsiębiorstw usługowych. Przeciętny poziom środków trwałych netto 9200 spółek z o.o. wynosił 500 mld RMB, co stanowiło 20,6 proc. wszystkich przemysłowych SOE i 24,9 proc. wszystkich $L M E^{33}$.

Część $L M E$, która osiaga lepsze wyniki finansowe zostaje wprowadzona, jako spółki akcyjne na giełdy w Szanghaju, Shenzhen, Hongkongu lub Nowym Jorku. Na chińskich giełdach istnieją dwa rodzaje akcji - akcje typu A, zarezerwowane dla inwestorów krajowych, akcje typu B, zarezerwowane dla inwestorów zagranicznych (od pewnego czasu do tego rynku dopuszczani są inwestorzy krajowi) oraz notowane na giełdzie w Hongkongu

${ }^{30}$ Por. G. E. Fryxell i C. W. H. Lo, Organizational Membership and Environmental Ethics: A Comparison of Managers in State-Owned Firms, Collectives, Private Firms and Joint Ventures in China, „World Development” 2001, Vol. 29, No. 11, s. 1941-1956.

31 Pełna nazwa NOM brzmi: „, Regulations on Transforming the Management Mechanism of State-Owned Industrial Enterprises".

32 R. Tung, Market-Oriented Reform of State-Owned Enterprises in Mainland China, ,Issues \& Studies", 1995, nr 2, s. 12.

33 R. Smyth, Toward..., cyt. wyd., s. 112. 
akcje typu H i akcje tzw. red chips. Na giełdzie w Nowym Jorku firmy chińskie reprezentowane są przez akcje typu $\mathrm{N}$.

\section{Konsolidacja w grupach przemystowych (korporatyzacja)}

Zamierzeniem władz chińskich jest nie tylko restrukturyzacja przedsiębiorstw państwowych, ale również przekształcenie ich w uznane korporacje międzynarodowe. Dlatego też konsekwentnie prowadzona jest polityka tworzenia międzyregionalnych i transprzemysłowych konglomeratów gospodarczych o różnej strukturze własności, których głównym celem ma być działalność międzynarodowa. Działania te oparte są na powszechnej opinii, że do takich molochów państwowych należy przyszłość, że wielkość jest warunkiem skutecznej rywalizacji z firmami zagranicznymi ${ }^{34}$. Na poziomie narodowym, Rada Państwa wspiera ponad 120 dużych grup przedsiębiorstw (qiye jituan), głównie w sektorze ciężkiego przemysłu (produkcja maszyn, metalurgia i chemikalia), utworzonych w drodze fuzji, zakupów i przejęć. Wiele $\mathrm{z}$ dużych przedsiębiorstw i grup przedsiębiorstw powstało na poziomie miast i prowincji, np. Szanghaju, Zhejiangu, Guangdongu czy Liaoningu ${ }^{35}$.

Największe grupy powstają w strategicznych sektorach, jak petrochemiczny. Do największych w tym sektorze należą:

- Dongliang Petrochemical Group, która powstała z połączenia czterech dużych przedsiębiorstw w Jiangsu: Jingling Petrochemicals, Yangzi Petrochemicals, Yizheng Chemical Fibre Company i Nanjing Chemical Fibre Company;

- Beijing Yanshan Petrochemical (Yanhua) Group będąca pod kontrolą państwowej China National Petroleum Corporation (Sinopec);

- Qilu Petrochemical Group, również pod kontrolą Sinopec.

Do równie istotnych sektorów, do których ChRL przykłada dużą uwagę należy przemysł motoryzacyjny i stalowy; tu powstały takie konglomeraty, jak:

- the First Automotive Works;

- the Second Automotive Works;

- the Nanjing Automotive Group;

- the Chongqing Automotive Group;

- grupy motoryzacyjne w Pekinie, Tianjinie, Szanghaju i Shenyangu;

- Wuhan Iron and Steel połączona z Daye Iron and Steel i Hubei Iron and Steel.

Wszystkie wymienione grupy emitują akcje zarówno na terenie kraju, jak i zagranicą. Dongliang Petrochemical Group, Yizheng Chemical Fibre Company, jako pierwsze spośród grup przemysłowych w 1997 r. wyemitowały akcje typu $\mathrm{H}^{36}$.

34 Tworzenie wielkich korporacji jest tendencją ogólnoświatową - choćby w UE działają, i to z sukcesem, wielkie korporacje, także państwowe. Por. także P. Yatsko, The Bigger, The Better, „,Far Eastern Economic Review”, 21 maja 1998, s. 11.

35 „China Daily”, 18 września 1997, s. 2.

36 „China Daily Business Weekly”, 14-20 września 1997, s. 1. 
Należy jednak podkreślić, że tego typu formy działalności obarczone są dużym ryzykiem ze względu na rozmiary, szerokie spektrum oferowanej produkcji, brak restrukturyzacji sposobów zarządzania, a także zbyt ścisłe powiązania z państwem. Przykładem tego mogą być koreańskie chaebole, czy japońskie keiretsu. Wielu ekonomistów uważa, że spora część fuzji i przejęć została wymuszona przez władze i nie jest oparta na ekonomicznych przesłankach. Głównymi motywami są założenia polityczne i ambicjonalne, dążące do wykreowania przekonania o mocarstwowości gospodarki Chin, ze świadomością, że organizmy o takiej wielkości mogą przynieść odwrotny od zamierzonego skutek, a mianowicie zmonopolizować rynek krajowy. Osobną kwestię stanowi wspomniany już zakres swobód udzielonych menedżerom, którzy będąc poza kontrolą państwa, przykładowo w latach 1982-1992 narazili firmy według State Administration of State Property na straty rzędu 500 mld RMB (87 mld USD) ${ }^{37}$.

Z pewnością koncerny globalne są potrzebne gospodarkom, czego przykładem jest Japonia, Wielka Brytania, czy USA, gdzie odpowiedzialne są one za prawie 30 proc. $\mathrm{PKB}$, ale organizmy te muszą funkcjonować na zdrowych fundamentach ekonomicznych - przede wszystkim nie mogą nieustannie generować „złych długów”.

\section{Nadzór nad restrukturyzacją dużych i średnich przedsiębiorstw państwowych}

W marcu 2003 r. powołano w Pekinie Komisję ds. Nadzoru i Zarządzania Państwowymi Aktywami (State-Owned Assets Supervision and Administration Commission of the State Council-SASAC). Funkcjonuje ona jako przedstawiciel państwa w nadzorowaniu działań największych chińskich przedsiębiorstw państwowych, wspierając jednocześnie ich ekonomiczną restrukturyzację ${ }^{38}$. Do podstawowych zadań Komisji, działającej w wyznaczonym przedsiębiorstwie jako inwestor, należy kontrola nad właściwym i efektywnym zarządzaniem majątkiem państwa, a tym samym powiększaniem jego wartości, a także ocena zarządów firm zgodnie z odpowiednimi zasadami. Celem Komisji jest również zapewnienie przejrzystości i otwartości procesów sprzedaży majątku państwa, ponieważ fundusze pochodzące z prywatyzacji będą wykorzystane w sektorze ubezpieczeń społecznych.

Utworzenie Komisji, koordynującej pracę lokalnych agencji zarządzania majątkiem państwowym (State-Owned Assets Administration Commission - SOAAC), pozwoliło na formalne oddzielenie funkcji zarządcy i inwestora. Nadzorowi Komisji podlega 196 największych przedsiębiorstw, których majątek pod koniec 2002 r. wyceniany był na 9,6 biliona RMB (833,3 mld USD) $)^{39}$.

37 P. Yatsko, Party”s Over, „Far Eastern Economic Review”, 5 czerwca 1997, s. 59.

38 Podstawę prawną stanowi prowizoryczna ustawa, wyznaczająca zakres relacji pomiędzy Komisją i jej agencjami a nadzorowanymi przedsiębiorstwami - Regulation for the Supervision and Management of Corporate State-Owned Assets.

39 Dla porównania w całych Chinach pod koniec 2002 r. znajdowało się około 174 tys. państwowych przedsiębiorstw. 


\section{Restrukturyzacja małych przedsiębiorstw państwowych}

W odróżnieniu od $L M E$, które pozostaną pod kontrolą państwa, małe przedsiębiorstwa państwowe są sprzedawane (zgodnie z koncepcją fangxiao). Rezultatem wspomnianego wyżej eksperymentu reformowania małych i średnich przedsiębiorstw w 18 pilotażowych miastach, było wprowadzenie różnych form reform instytucjonalnych ${ }^{40}$. W cytowanej uprzednio prowincji Zhejiang małe przedsiębiorstwa restrukturyzowano za pomoca przejęć, upadłości (w latach 1990-1996 łączna liczba bankructw małych przedsiębiorstw państwowych wyniosła 11,5 tys.), zawieszania działalności, leasingu i powiernictwa ${ }^{41}$.

Z pewnością mnogość eksperymentów przyniosła z jednej strony sporą ilość pozytywnych efektów, jak zmniejszenie roli państwa w zarządzaniu, odpowiedzialność pracowników za losy firmy, możliwość uzyskiwania funduszy z emisji udziałów. Zaistniało jednak również wiele negatywnych skutków, jak niemożność zakupu udziałów przez pracowników ze względu na brak środków, co jest równoznaczne z utratą pracy (dotyczy to głównie niewykwalifikowanych robotników w przemysłach: tekstylnym, wydobywczym, hutniczym, stoczniowym i chemicznym). Przekształcenia przedsiębiorstw powodują ponadto uszczuplenie zasobów państwa; ocenia się, że tą drogę państwo traci 50 mld RMB rocznie ${ }^{42}$.

Początkowo rząd chiński niechętnie szukał możliwości restrukturyzacji przedsiębiorstw poprzez przeprowadzanie upadłości. Wynikało to z potencjalnych, negatywnych socjoekonomicznych skutków redukcji na tak wielką skalę. W 1990 r. zanotowano tylko 32 upadłości, ale już w 1995 r. było ich prawie dziesięć razy więcej, z czego tylko 103 $\mathrm{W}$ rejonach eksperymentalnych ${ }^{43}$. Majątek części zbankrutowanych przedsiębiorstw jest wchłaniany przez grupy przemysłowe, reszta jest likwidowana, przy czym należy podkreślić, że upadłości byłoby więcej, gdyby przestrzegano prawa upadłościowego ${ }^{44}$.

Jedną z metod reformowania małych przedsiębiorstw państwowych było również przekształcenie ich w organizmy o akcyjnej/udziałowej strukturze własności (kooperatywnym systemie własności - gufen hezuo zhi $)^{45}$. Po raz pierwszy zastosowano takie podejście w Zhucheng w prowincji Shandong i w Zhengding w prowincji Hebei w 1993 r. i 1994 r. odpowiednio i zostało ono zaakceptowane w 1997 r. przez XV Zjazd KPCh.

40 Por. G. Lihong, The Unfeasible „, Measures for the Reduction of the Holding of Shares” and the Necessary Reduction of the Holding of State Assets, „China Development Review”, (Pekin) 2002, vol. 4., nr 2, s. 49-63.

${ }^{41}$ Summary of World Broadcasts, „Asia and the Pacific”, Część 3., 26 lutego 1998.

42 Wynika to następujących przyczyn - zasoby przedsiębiorstw są albo niedoszacowane albo zupełnie nieoszacowane lub też przekazywane są za darmo (często urzędnikom państwowym lub ich rodzinom). Powoduje to niechęć do sprzedaży, gdyż nieprawidłowości mogłyby wyjść na jaw, a także sprzedaż mogłaby spowodować utratę pracy przez zarządy.

43 Losses Grow for Chinese Industry, „International Herald Tribune”, 15 marca 1996.

44 Obecnie obowiązuje Ustawa o bankructwach chińskich przedsiębiorstw państwowych (Law of the People's Republic of China on Enterprise Bankruptcy) z 2 grudnia 1986 r. Trwają prace nad jej nowelizacja.

45 P. Yatsko, Owner Power, „Far Eastern Economic Review”, 21 maja 1998, s. 14. 
Jest to przykład dość powszechnej inicjatywy oddolnej, która została wykorzystana przez reformatorów jako powszechnie stosowane podejście. Wiele nowych rozwiązań o zasięgu krajowym z reguły sprawdzano w formie „eksperymentów lokalnych” lub korzystano z takich doświadczeń przy konstruowaniu propozycji reform zgodnie z reguła pragmatyzmu.

Władze municypalne $\mathrm{w}$ wielu prowincjach także poświęcają sporo energii, aby przyciągnąć przedsiębiorców, szczególnie zagranicznych, do inwestycji w przedsiębiorstwa państwowe ${ }^{46}$. Preferencyjne warunki zakupu (w przypadku wykupu przedsiębiorstwo przyjmuje formę albo spółki joint venture albo przedsiębiorstwa zagranicznego - wholly-owned foreign enterprise WOFE - jeśli nastapił całkowity wykup), umarzanie długów, obniżanie podatków, częściowe zakupy, transakcje barterowe itp. Częstym zjawiskiem w przypadku sprzedaży przedsiębiorstw jest pośrednictwo brokerów, nazywanych też centrami obrotu prawami własności, którzy poszukują odpowiednich inwestorów ${ }^{47}$. Pierwsze tego typu przedsięwzięcie powstało w Chengdu w 1988 r., odnotowując do 1993 r. 275 fuzji i przejęć, z czego 80 proc. stanowily transakcje dotyczące przedsiębiorstw państwowych, o wartości 1,5 mld $\mathrm{RMB}^{48}$.

Najlepszym przykładem dynamicznego procesu sprzedaży jest uznawana za bastion przemysłu państwowego północno-wschodnia prowincja Liaoning, gdzie pod koniec lat 90. według State Economic and Trade Commission - SETC sprzedano 60 proc. LME ${ }^{49}$ oraz Szanghaj, w którym większość SOE (w 2001 r. wartość przedsiębiorstw państwowych, będących w rękach władz municypalnych była oceniana na 48 mld $\mathrm{USD}^{50}$ ) była pod nadzorem 39 państwowych korporacji holdingowych- $S H C S^{51}$, (warto w tym miejscu wspomnieć o Local Developmental State - LDS oraz Local State Corporatism - LSC funkcjonujących jako przybudówki administracji lokalnej, służące rozwojowi miejscowej przedsiębiorczości; można je uznać w części za protoplastów wspomnianych grup sektorowych ${ }^{52}$ ) skupiających państwowe przedsiębiorstwa pod bezpośrednią kontrolą lokalnego Komitetu Administracji Środkami Publicznymi - SOAAC.

Ocenia się, że łączna wartość przedsiębiorstw państwowych np. w Szanghaju wynosi około 500 mld RMB; reprezentują one 85 branż, z czego 23 są nierentowne $(8,3$ proc.

46 P. Yatsko, Chinese Fire Sale, „Far Eastern Economic Review”, 21 maja 1998, s. 15.

47 „China Daily”, 18 kwietnia 1998, s. 4.

48 China's Management of Enterprises Assets: The State as Shareholder, The World Bank, Waszyngton 1997, s. 10.

49 K. Wilhelm, Out of Business, „Far Eastern Economic Review”, 18 lutego 1999, s. 10.

50 D. Murphy, Shanghai's Great Leap, „Far Eastern Economic Review”, 9 sierpnia 2001, s. 40.

51 Przekształconych z 14 grup sektorowych, odpowiedzialnych za poszczególne gałęzi gospodarki.

${ }_{52}$ M. Blecher, Development State, Enterpreneurial State: the Political Economy of Socialist Reform in Xinju and Guanghan county, [w:] G. White (red.), The Chinese state in the era of economic reform, Macmillian, Londyn 1991, s. 265-291 oraz J. C. Oi, The Role of the Local State in China's Transitional Economy, „The China Quarterly”, 1995, nr 144, s.132-49. 
całej wartości $)^{53}$. Środki uzyskiwane w Szanghaju ze sprzedaży przedsiębiorstw państwowych przeznaczane były w dużej mierze na rozwój krajowych przedsiębiorstw sektora high-tech.

Dużym zainteresowaniem władz (przede wszystkim prowincjonalnych i powiatowych) cieszą się fuzje, przejęcia i włączenia jako jedna z podstawowych metod restrukturyzacji przedsiębiorstw. Wynika to z obawy przed konsekwencjami likwidacji, przyczyniających się do wzrostu bezrobocia i niepokoju społecznego ${ }^{54}$. Fuzje w intencji władz mają również przyczynić się do efektywniejszego zarządzania zasobami i wzrostu przewagi konkurencyjnej w stosunku do zagranicznych przedsiębiorstw.

\section{Przedsiębiorstwa prywatne}

W przeciwieństwie do prywatyzacji w Europie Wschodniej, tę w Chinach należy postrzegać przede wszystkim jako „prywatyzację przedsiębiorczą”, tzn. jako typowy dla chińskich reform spontaniczny proces tworzenia przedsiębiorstw, który rozpoczął się na wsi wśród chłopów ${ }^{55}$. Jednocześnie jednak chińscy przedsiębiorcy przetrwali aż do „rewolucji kulturalnej”. Tradycje przedsiębiorczości rodzinnej z trudem tłumiono i to tylko okresowo. Przykładowo „małe brygady produkcyjne” xiaoshengchang dui, sprzed „rewolucji kulturalnej” były dość autonomicznymi przedsiębiorstwami, nie tylko rolnymi, często prowadzonymi przez wielką rodzinę. Poza powszechnym niskim poziomem życia i licznymi niezaspokojonymi potrzebami (oficjalnie nie było przeciwstawienia bieda-bogactwo), inne czynniki odegrały ważną rolę w rozpoczęciu reform: silne dążenie chłopstwa ku prywatnej własności i rodzinnej gospodarce, pewna autonomia chłopstwa wobec państwa oraz tolerowanie przez kierownictwo partyjne ograniczonych form działalności prywatnej.

W latach 50. niemal wszystkie zakłady prywatne zostały przekształcone w państwowe lub spółdzielcze. Inaczej jednak niż w Polsce w wielu przypadkach zachowano współwłasność dawnych właścicieli, a nawet niekiedy ich funkcje dyrektorskie! Aż do „rewolucji kulturalnej” wypłacano im zyski, a „patriotyczna burżuazja” była uznawana. Uspółdzielczenie też często było fomalne, bo pozostawał na przykład ten sam warsztat i właściciel - tyle, że nad sobą miał jakieś organy nadzorcze.

Jakakolwiek forma self-employment została zabroniona wraz z „rewolucją kulturalną". Podjęte wówczas działania zmierzające ku całkowitej eliminacji rynku, zysku i mechanizmów ekonomicznych jako „kapitalistycznych” oficjalnie osiaggnęły swój punkt

53 C. Devonshire-Ellis, Purchasing State - Owned Enterprises, „Beijing Review”, 25 września 2003, s. 37.

${ }^{54}$ P. Yatsko, Urge to Merge, „Far Eastern Economic Review”, 23 maja 1996 r., s. 56.

55 T. Heberer, Pomiędzy kryzysem a szansq: nowe społeczne wyzwania ze szczególnym uwzględnieniem wiejskich Chin, [w:] Chiny przemiany państwa i społeczeństwa $w$ okresie reform 1978-2000, Praca zbiorowa pod kierunkiem prof. dr hab. K. Tomala, Instytut Studiów Politycznych Polskiej Akademii Nauk, Warszawa 2001, s. 77. 
szczytowy w połowie lat 70. wraz z kampanią „uczyć się od Dazhai i od Daqing" 56 . Jednocześnie od 1972 r. po cichu i stopniowo powracano do tych praktyk, bo „banda czworga" nie interesowała się gospodarką i zarządzaniem. Ruch „uczyć się od Dazhai i od Daqing" miały zatem głównie charakter fasadowy. Przedmiotem kampanii była redukcja wszelkiej działalności gospodarczej do kolektywów, przy jednoczesnym napiętnowaniu powstawania spontanicznych ,nielegalnych” rynków oraz prywatnej działalności gospodarczej - wyraźny znak ich ponownego powstawania ze względu na szeroko występująca na terenach wiejskich biedę. Kryzys legitymacji władzy po śmierci Mao pociagnął za sobą spontaniczny rozwój prywatnej działalności gospodarczej oraz, w końcu, dopuszczenie gospodarowania indywidualnego, początkowo bez zezwolenia na odpłatne zatrudnianie. Ponieważ coraz więcej gospodarstw indywidualnych zatrudniało „członków rodziny” lub „krewnych”, praca za wynagrodzeniem stała się rychło faktem.

Dopiero jednak w marcu 1979 r. przywódcy polityczni oficjalnie zezwolili na powrót gospodarki indywidualnej, która wcześniej funkcjonowała, ale bez zezwoleń. Przepis z lipca 1981 r. określał zakład prywatny zatrudniający kilku pracowników za wynagrodzeniem, jako konieczne uzupełnienie gospodarki państwowej oraz kolektywnej. Prowadzących działalność indywidualną określano jako „pracowników socjalistycznych”, co formalnie zrównało ich z robotnikami i chłopami. W sierpniu $1987 \mathrm{r}$. uchwalono przepisy o indywidualnych wiejskich zakładach przemysłowych i handlowych, zezwalające na zatrudnienie do siedmiu osób. Prawie rok później Rada Państwa wydała „Prowizoryczne warunki dla prywatnych przedsiębiorstw", legalizujące prawnie oraz politycznie przedsiębiorstwa zatrudniające więcej niż siedmiu pracowników. Tym samym zniesiono ograniczenie w odpłatnym zatrudnianiu. Od tego czasu zakład prywatny zatrudniający mniej niż siedmiu pracowników traktowany był jako przedsiębiorstwo indywidualne, a zatrudniający więcej niż siedmiu pracowników jako przedsiębiorstwo prywatne.

Jednocześnie jednak dość późno, bo w 1997 r. częściowo zniesiono ograniczenia dla prywatnych przedsiębiorców w odniesieniu do wprowadzania akcji firm na giełdy, ponieważ stanowić one miały źródło finansowania głównie dla nieefektywnych przedsiębiorstw państwowych, a przedsiębiorstwa prywatne stanowiły konkurencję dla tych zamierzeń. Przyjęto określoną listę przedsiębiorstw, którym zezwolono przeprowadzać publiczne emisje akcji, dlatego w 2002 r. z 1154 spółek na giełdach w Shenzhen i Szanghaju jedynie 24 to przedsiębiorstwa prywatne (np. Minsheng Bank, UF Soft ${ }^{57}$, a całkowita liczba spółek prywatnych obecnych pod koniec 2003 r. na giełdach chińskich wynosiła około $150^{58}$. Ograniczenia te powoduja, że wielu prywatnych przedsiębiorców rozważa debiut giełdowy poza granicami ChRL, głównie w USA i Singapurze oraz Hongkongu, który nadal jest atrakcyjnym miejscem do zorganizowania publicznej oferty akcji.

56 Tamże.

57 B. Gilley, Going Public in China, „Far Eastern Economic Review”, 17 stycznia 2002, s. 52.

58 Należy jednak podkreślić, że mała liczba notowanych spółek prywatnych, w opinii np. PricewaterhouseCoopers, wynika także z mniejszej przejrzystości w ich funkcjonowaniu w porównaniu do przedsiębiorstw państwowych. 
Mylnie byłoby jednak obecnie wnioskować o możliwości miękkiego przejścia do gospodarki rynkowej według wzorów europejskich ${ }^{59}$. Z jednej strony brakuje instrumentów prawnych, mogących dać sektorowi prywatnemu pewność, z drugiej strony w przypadku „socjalistycznej gospodarki rynkowej” Chin mamy do czynienia z regulowaną państwowo, tzn. budżetową, formą gospodarki. Sektor prywatny, mimo formalno-prawnej równości, jest dyskryminowany przez lokalne władze, upośledzony przy zaopatrzeniu oraz zbycie i obłożony nadmiernymi podatkami oraz świadczeniami na rzecz państwa, co niekorzystnie wpływa na jego stały rozwój. Boryka się on z potężnymi ograniczenia rozwoju, jak dostęp do rynku, surowców, kredytów, kapitału lub licencji eksportowych, nabywanie powierzchni handlowych lub lokalizacji sklepów, liczne narzucane samowolnie opłaty, repartycje i dodatkowe świadczenia na rzecz władz lokalnych, a także wysokie obciążenia podatkowe. Kolejnymi utrudnieniami są bariery biurokratyczne, społeczne uprzedzenia, czy zwykła zazdrość. Do tego dochodzą problemy polityczne, jak częste zmiany lokalnej oraz centralnej polityki, częściowe zaklasyfikowanie zatrudnienia w sektorze prywatnym jako „wyzysku”, a prywatnych przedsiębiorców jako „nowych kapitalistów".

Sektor prywatny, mimo wskazanych trudności, okazał się niezwykle dynamiczny i stał się filarem podpierającym rozwój ekonomiczny. $Z$ tego też względu szybko zmieniła się jego polityczna ocena przez partię. Kierownictwo partii zaczęło tolerować w ograniczonym zakresie prywatną gospodarkę, która jako „uzupełnienie socjalistycznej gospodarki” miała stać się częścią docelowej „socjalistycznej gospodarki rynkowej” ${ }^{\circ}$. W celu wzmocnienia osiagniętego kompromisu, podzielono sektor prywatny na różne kategorie, których nie określano jako prywatne, ale jako „gospodarka obywatelska”, „gospodarka prowadzona przez ludność”, „,gospodarka rodzinna”, „gospodarka budżetowa”, „gospodarka rolna indywidualna". Nawet gospodarowanie rodzinne w sektorze rolniczym nie jest traktowane jako prywatna działalność gospodarcza, lecz „rodzinna”. Opublikowana pod koniec 1995 r. lista 500 największych chińskich przedsiębiorstw prywatnych wykazuje roczne obroty dla poszczególnych z nich od 1,6 mld do 11, 1 mld RMB. Stąd też „czynnik uzupełniający” staje się powoli elementem dźwigającym gospodarkę, tym bardziej że nie musi być, tak jak sektor państwowy, dotowany przez państwo, lecz stanowi dla niego źródło wzrastających dochodów. Również w 1995 r. kierownictwo partyjne uznało za konieczne wydanie oświadczenia o możliwości równoległego i równoprawnego rozwoju wszystkich form własności. Przede wszystkim prosperujące wschodnie prowincje określały obecnie sektor prywatny jako „motor socjalistycznej gospodarki rynkowej”. XV Zjazd KPCh określił ten sektor nawet jako część sektora „socjalistycznego”. Według danych Ogólnochińskiej Federacji Przemysłu i Handlu Chiny w 1996 r. miały 820 tys. przedsiębiorstw prywatnych zatrudniających prawie $12 \mathrm{mln}$ osób i produkujących towary o wartości 39 mld USD. Pięć lat później tych firm było 2,2 mln, zatrudniały one $29 \mathrm{mln}$ osób, a wartość ich produkcji skoczyła do 89 mld USD.

\footnotetext{
59 T. Heberer, cyt. wyd., s. 79.
}

60 Tamże. 
Według Banku Światowego prywatnie wytwarzana jest ponad połowa chińskiego dochodu narodowego, niezależni ekonomiści chińscy i zachodni uważaja, że jest to nawet około 70 proc. W 1999 r. wpisano do konstytucji ochronę ,praw i interesów” gospodarki prywatnej, jednak nie własność prywatną jako taka.. Mimo, że już w 1993 r. Chiny stały się oficjalnie „socjalistyczną gospodarką rynkową” biznesmeni wciąż narzekają na dyskryminację w sądach czy w bankach państwowych. Tymczasem partia potrzebuje pomocy prywatnego biznesu, bo zdecydowała się na prywatyzację i liczy na sektor prywatny, by amortyzować bezrobocie i utrzymać dynamikę gospodarczą. Zdecydowała się nawet na zaproszenie prywatnych przedsiębiorców w jej szeregi, co stanowi podstawę do dość powszechnego, choć ironicznego określenia, że CCP (Chinese Communist Party) oznacza w praktyce Chinese Capitalist Party.

Wprowadzenie konstytucyjnej ochrony własności prywatnej świadczy o tym, że po raz pierwszy od 1949 r. Chiny uznają własność prywatną i biorą ją pod ochronę: „Własność prywatna legalnie nabyta nie może być naruszana" - brzmi poprawka do konstytucji. Dlatego też wielu specjalistów od pewnego czasu pisze o demontażu czy upadku komunizmu w Chinach, uważając, że nazywanie ich „komunistycznymi” z ekonomicznego punktu widzenia jest nieuzasadnione. Przez wiele lat, zgodnie z doktryną marksistowska, komunistyczna konstytucja uznawała tylko dwa rodzaje własności: państwową (określaną jako „święta i nienaruszalna”) i osobistą. O poprawkach do konstytucji zadecydowano dopiero w październiku 2003 r. na plenum KC KPCh, któremu przewodniczył po raz pierwszy nowy sekretarz generalny i prezydent $\mathrm{w}$ jednej osobie - Hu Jintao ${ }^{61}$.

\section{Państwowe przedsiębiorstwa prywatne}

W kontekście niezwykłego rozwoju sektora prywatnego niezbędne jest również zwrócenie uwagi na niezwykle interesującą i innowacyjną formę działalności prywatnej w Chinach, a mianowicie przedsiębiorstwa prywatne, zakładane od początku lat 90 . przez biurokrację państwową (przede wszystkim w rolnictwie, przemyśle zbrojeniowym $i$ handlu, choć zdarzają się nawet restauracje). Pierwowzorem były przedsiębiorstwa qua$s i$-państwowe, które zysk opierały na omawianym wcześniej systemie cen dualnych ${ }^{62}$. Ich podstawowym założeniem było przynoszenie dodatkowego zysku dla administracji, przeznaczanego przede wszystkim na premie, remonty biur i nowe technologie oraz zatrudnianie zwalnianych urzędników państwowych ${ }^{63}$. Nie były to przedsięwzięcia planowane, ujęte jako metoda reform gospodarczych, były to raczej spontaniczne inicjatywy w ramach dynamicznej transformacji i nieprecyzyjnego prawa. Równolegle nie można ich zaklasy-

${ }^{61}$ Chiny wprowadzaja konstytucyjna ochrone własności prywatnej, „Gazeta Wyborcza”, 22 grudnia 2003.

${ }^{62} \mathrm{Qi} \mathrm{Li}$, ,, Shiti re” chutan (Initial Study of the Craze for Economic Entities), „Liaowang” (Outlook), 10, sierpień 1992, s. 9-11.

63 Zhongguo Minzheng (Civil Affairs in China), 1996 (2), s. 32. 
fikować jako przedsiębiorstw państwowych, nie są one nawet powszechnie rejestrowane, gdyż władza centralna nigdy jednoznacznie nie zaakceptowała tego rozwiązania.

Z pewnością jest to propozycja reformowania administracji państwowej i gospodarki centralnie planowanej, wynikająca jednoznacznie ze specyfiki transformacji chińskiej, nie nadająca się do powielenia w innych transformujących się systemach polityczno-gospodarczych. Forma ta budzi zdecydowanie sporo obaw ${ }^{64}$, ponieważ jako organizacje funkcjonujące $\mathrm{w}$ mechanizmie rynkowym wystawione są one na ryzyko, konkurencję, a jednocześnie finansowane są z pieniędzy państwowych, nad którymi rząd $i$ władze lokalne mają ograniczoną kontrolę ${ }^{65}$. Jeszcze większe wątpliwości budzi fakt, że przedsiębiorstwa takie mogą pokrywać korupcyjne i nielegalne transakcje prowadzone przez urzędników państwowych wysokiego szczebla, którzy łączą służbę cywilną z prowadzeniem firm ${ }^{66}$. $Z$ drugiej jednak strony, przedsiębiorstwa te wsparły proces redukcji administracji poprzez zatrudnianie redukowanych urzędników, umożliwiły podwyżki płac służby cywilnej oraz wprowadziły większe zrozumienie mechanizmów rynkowych wśród kadry urzędniczej.

\section{Efekty powstania sektora prywatnego}

Sektor prywatny oraz rynek stworzyły nowe możliwości zarabiania pieniędzy oraz awansu społecznego zmieniając w ten sposób istniejący schemat warst $w^{67}$. Uwarunkowane prywatyzacją oraz ekonomizacją polityki nowe możliwości zarobków oraz dochodów są przyczyną dysproporcji płacowych, rosnącej nierówności a przez to różnicowania oraz polaryzacji społeczeństwa. Dzięki wykorzystywaniu szans oraz luk na rynku, kontroli ważnych surowców (funkcjonariusze) lub właściwym kontaktom z lokalnymi kadrami (przedsiębiorcy), przez działalność legalną, nielegalną, kryptoprywatną lub w szarej strefie, dzięki spekulacji i korupcji można osiagnać znaczne dochody. Na wsi znacznie wyższe dochody w sektorze nierolniczym powiększają lokalne rozbieżności w zarobkach i standardzie życia. Zarazem powstają nowe warstwy. Rynek wykształcił więc nowe źródła władzy, nawet jeśli przejawia się ona początkowo jedynie ekonomicznie.

Zasadniczo na wsi można wyróżnić kilka grup warstw ${ }^{68}$ :

${ }^{64}$ Właśnie prywatyzacja nomenklaturowa budziła największe kontrowersje i protesty. Np. słynny protest studencki z 1989 r. miał to za jeden z głównych punktów, demokrację dołączono dopiero potem, po części na zapotrzebowanie mediów zagranicznych.

65 J. Duckett, Bureaucrats in Business, Chinese-Style: The Lessons of Market Reform and State Enterprenerialism in the People's Republic of China, „World Development” 2001, Vol. 29, nr 1, s. 23,

${ }^{66}$ G. White, Corruption and Market Reform in China, „IDS Bulletin” (University of Sussex, Brighton), 1996, 27 (2), s. 40-47; J. Wong, Power and Market in Mainland China: the Danger of Increasing Government Involvement in Business, „Issues \& Studies” 1994, nr 2, s. 1-12.

${ }^{67}$ T. Heberer, cyt. wyd., s. 79.

68 Tamże, s. 80. 
- warstwy z wysokim statusem - wiodące kadry aparatu partyjnego oraz administracyjnego, menedżerowie większych nieprywatnych przedsiębiorstw, ważniejsi prywatni przedsiębiorcy o znacznym miejscowym potencjale finansowym, ew. ważnych powiązaniach społecznych;

- warstwy o wyższym statusie - pozostali lokalni funkcjonariusze, inteligencja (nauczyciele, lekarze, technicy), pozostali ważniejsi prywatni przedsiębiorcy, menedżerowie mniejszych wiejskich przedsiębiorstw;

- warstwy o przeciętnym statusie - zatrudnieni w kolektywach, drobni prywatni przedsiębiorcy;

- warstwy o niskim statusie - zatrudnieni na umowę w kolektywach, pracownicy przedsiębiorstw prywatnych, drobni rolnicy, pracownicy migrujący z zewnątrz.

Lokalna elita gospodarcza składa się z menedżerów wiejskich zakładów kolektywnych i dobrze prosperujących prywatnych przedsiębiorców. Pierwsi rekrutują się z dość często czynnych i byłych kadr lub z osób z dobrymi kontaktami z elitą polityczną. W dużej mierze chodzi tu o byłe kadry administracyjne ${ }^{69}$. Najbardziej intratne są stanowiska menedżerskie w większych przedsiębiorstwach. Wiejskie zakłady są zazwyczaj dzierżawione przez menedżerów, przy czym otrzymują oni za wykonanie przewidzianych umową wytycznych z reguły 1-3 proc. zysku w formie bonów. W przypadku nieosiagnięcia norm zmniejsza się premia, w razie ich spełnienia, pokaźnie wzrasta.

Wśród prywatnych przedsiębiorców większość stanowią byli funkcjonariusze, wysłani na wieś absolwenci szkół średnich z miast, członkowie przedrewolucyjnych elit, byli przedsiębiorcy i niegdysiejsi wojskowi. Grupy te są zazwyczaj odpowiednio wykształcone i doświadczone lub mają dobre kontakty z miejscową biurokracją.

We wsiach politycznymi wyroczniami są członkowie kierownictwa komitetu partyjnego lub komitetu administracyjnego wsi. Jeżeli jeszcze kontrolują wiejskie zakłady, tworzą także elitę finansową. Poza nimi we wsiach istnieje elita przedsiębiorców składająca się z ludzi interesu, zamożnych gospodarzy oraz menedżerów wiejskich zakładów (zazwyczaj kadry lub ich rodziny). Stosunkowo ważną rolę odgrywa tradycyjna elita: starsi członkowie klanów i religijne osobistości ${ }^{70}$. W większości wsi między elitami nawiązały się rozmaite zależności. Polityczna i ekonomiczna władza wydają się tu najbardziej mieszać.

Powszechnie postępujące od początku lat 90. rozwarstwienie społeczne uwidoczniło zasadnicze różnice między uwarstwieniem przed i po rozpoczęciu reform. Przedtem różnice między warstwami miały swoje podłoże głównie w kryteriach politycznych, przy czym przynależność do partii, miejsce w hierarchii, pochodzenie klasowe i stabilność ideologiczna była warunkiem przynależności do elity, a osoby będące ,wrogiem klasowym”, jak byli właściciele ziemscy, bogaci rolnicy oraz członkowie ich rodzin i dawnej elity władzy, należeli do najniższej warstwy. Pochodzenie rodzinne i status klasowy były w znacznej mierze tożsame. Od początku XXI w. natomiast istnieje uwarstwienie opie-

$\begin{array}{ll}69 & \text { Tamże. } \\ & \\ 70 & \text { Tamże. }\end{array}$ 
rające się w większej mierze na przesłankach ekonomicznych (sukces gospodarczy i finansowy). Zróżnicowanie systemu własności, społeczna mobilność i wzrastający podział pracy tworzą podstawowe przyczyny powiększania się różnic w dochodach i społecznej stratyfikacji, przy czym rozwój tej tendencji w tak krótkim czasie jest znaczny.

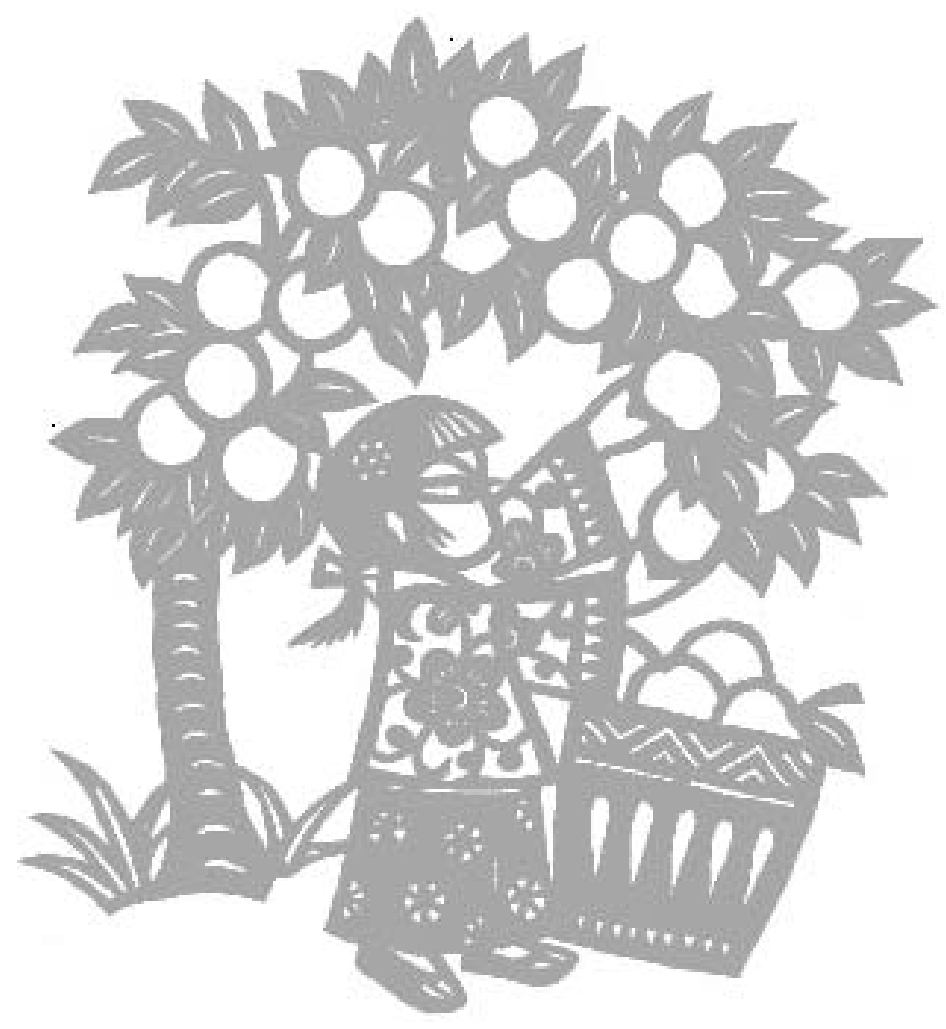

